Polonia Sacra 18 (2014) nr 3 (36) · s. 47-58

Jacek Kiciński CMF1

Papieski Wydział Teologiczny we Wrocławiu

\title{
Powołanie w jesieni życia według św. Jana Pawła II
}

Ojciec święty Jan Paweł II w swojej programowej encyklice Redemptor hominis zwrócił szczególną uwagę na człowieka i jego odniesienie do Boga. Podkreślił tym samym, że człowieka nie da się zrozumieć bez Chrystusa (zob. RH 10). Dopiero w tajemnicy Jego życia odczytujemy istotę rodzaju ludzkiego. Doświadczenie Boga - Miłości, który w pełni objawił się w osobie Chrystusa, pokazuje, że podstawą powołania każdego człowieka jest miłość. Dlatego też, jak zaznacza św. Jan Paweł II, „człowiek nie może żyć bez miłości. Człowiek pozostaje dla siebie istotą niezrozumiałą, jego życie pozbawione jest sensu, jeśli nie objawi mu się Miłość, jeśli nie spotka się z Miłością, jeśli jej nie dotknie i nie uczyni w jakiś sposób swoją, jeśli nie znajdzie w niej żywego uczestnictwa. I dlatego właśnie Chrystus-Odkupiciel [...] objawia w pełni człowieka samemu człowiekowi" ${ }^{2}$. Zatem człowiek, jeśli chce zrozumieć sens swojego życia i powołania, winien z całą swoją otwartością, niepoko-

Dr hab. Jacek Kiciński CMF, prof. PWT, ur. 30 sierpnia 1968 roku w Turku, kapłan Zgromadzenia Misjonarzy Klaretynów, święcenia 27 maja 1995 roku, doktorat KUL 2000, habilitacja PWT 2010, profesura tytularna PWT 2012. Kierownik Katedry Duchowości Kapłańskiej i Życia Konsekrowanego PWT, redaktor naczelny dwumiesięcznika „Życie Konsekrowane”, dyrektor Podyplomowych Studiów Teologii Życia Konsekrowanego PWT. Autor 3 książek i ponad 50 artykułów w zakresie duchowości chrześcijańskiej. Ostatnie publikacje książkowe: Powołanie - konsekracja - misja. Personalistyczny aspekt teologii życia konsekrowanego we wspótczesnym Magisterium Kościoła, Wrocław 2009; Duchowość misji współdzielonej, Wrocław 2013.

2 Jan Paweł II, enc. Redemptor hominis [dalej: RH], 10. 
jem, a zarazem słabością i grzesznością, ze swoim życiem i śmiercią, przybliżyć się do Chrystusa3. „Musi niejako w Niego wejść z sobą samym, musi niejako przyswoić, zasymilować całą rzeczywistość Wcielenia i Odkupienia, aby siebie odnaleźć" (RH 10).

Święty Jan Paweł II, wskazując na różnorodność powołań, posłużył się ewangeliczną przypowieścią o gospodarzu, który wzywa robotników do swojej winnicy o różnych porach dnia (zob. Mt 20, 1n). Pory te porównane są do kolejnych etapów życia człowieka. Jest to także pewne odniesienie do bogactwa powołań w Kościele. Każdy bowiem człowiek należący do wspólnoty Ludu Bożego zostaje zaproszony do świętości niezależnie od wieku, płci, przymiotów, a także sytuacji życiowej

\section{Powołanie człowieka darem i zadaniem}

Nawiązując do przypowieści o gospodarzu winnicy zapraszającym do niej robotników o różnych porach dnia, ojciec święty Jan Paweł II wskazuje za św. Grzegorzem Wielkim na różnorodność powołań w Kościele. I tak wspomniany święty porównuje pory dnia z etapami życia człowieka. Można według niego przyjąć, że ranek wskazuje na czas dzieciństwa; godzina trzecia to czas dorastania; godzina szósta oznacza młodość, zaś początek starości wyznacza godzina dziewiąta. Godzina jedenasta oznacza jesień życia, czyli wiek już podeszły (zob. ChL 45).

Spoglądając na ludzi starszych, Jan Paweł II pragnie ukazać im dalszą perspektywę realizacji powołania, choć jest to trudny etap ludzkiej egzystencji, który wiąże się z doświadczeniem ograniczonej sprawności fizycznej, a często także intelektualnej. Papież pokazuje, że obecność osób dorosłych w społeczeństwie zawsze jest nieodzowna. W adhortacji apostolskiej Christifideles laici poświęconej powołaniu i misji osób świeckich w Kościele i świecie pisał tak:

\footnotetext{
3 Zob. W. Zyzak, Co mam czynić, aby osiagnaćc życie wieczne? Duchowość chrześcijańska na świeckiej drodze życia, Kraków 2008, s. 236-242.

4 Zob. Jan Paweł II, adhort. apost. Christifideles laici [dalej: ChL], 45; zob. Katechizm Kościoła katolickiego, Poznań 1994, 2012-2016.
} 
Ludziom starszym, którzy często i niesłusznie są uważani za zbędnych, a nawet za nieznośny ciężar, pragnę powiedzieć, że Kościół prosi i od nich oczekuje, że będą kontynuowali swoją misję apostolską i misyjną, która nie tylko jest w ich wieku możliwa i potrzebna, ale właśnie dzięki ich wiekowi niejako otrzymuje specyficzny i oryginalny wymiar (ChL 48)5.

Słowa te w sposób szczególny zabrzmiały podczas przemówienia Jana Pawła II do przedstawicieli ludzi starszych z diecezji włoskich. Wówczas to papież powiedział do nich:

Wejście w tak zwany trzeci wiek należy uznać za przywilej nie tylko dlatego, że nie wszyscy mają szczęście przekroczyć ten próg, ale także i przede wszystkim dlatego, że jest to okres, w którym można lepiej przemyśleć i ocenić przeszłość, głębiej poznać i przeżyć tajemnicę paschalną, stać się w Kościele wzorem dla całego Ludu Bożego [...]. Pomimo że musicie rozwiązywać wiele złożonych problemów, że stopniowo ubywa wam sił, mimo niewystarczalności organizacji społecznych, zapóźnienia ustawodawstwa, niezrozumienia ze strony egoistycznie nastawionego społeczeństwa, nie jesteście i nie powinniście uważać się za ludzi żyjących na marginesie Kościoła; bierny element świata, który żyje w zbyt szybkim tempie, ale za czynne podmioty przeżywające płodny pod względem duchowym i ludzkim etap ludzkiego życia. Macie jeszcze misję do spełnienia, macie jeszcze wiele do ofiarowania. Wedle Bożego planu każda ludzka istota jest życiem, które stale wzrasta, począwszy od pierwszej iskierki istnienia, aż do ostatniego tchnienia 6 .

Każdy zatem, przeżywając jesień swojego życia, winien nie tylko dobrze spożytkować ten czas, ale wnieść w świat, zwłaszcza młodych ludzi, swoje głębokie doświadczenie życiowe poparte osobistą dojrzałością oraz mądrością, jaką zdobył podczas minionych lat życia?.

Mając to wszystko na uwadze, św. Jan Paweł II pokazuje, że każdy etap ludzkiego życia może stać się dla człowieka wielkim darem Boga, a jednocześnie kolejnym zadaniem do wypełnienia. Tym bardziej gdy mamy na uwadze starość, której przecież nie wszyscy dożywają․ (2006), s. 10.

6 Jan Paweł II, Przemówienie do przedstawicieli ludzi starszych z włoskich diecezji (23 marca 1984), „Insegnamenti” VII (1984) 1, 744.

7 Zob. J. Kiciński, Jesień życia - koniec czy początek?, „Studia Salvatoriana Polonica” 6 (2012), s. 213.

Zob. A. Pronzato, Starość czasem nadziei, przeł. A. Ryndak-Laciuga, Kraków 2005, s. 31-37. 


\section{Dobrze przeżyć dar życia}

Ukazując jesień ludzkiego życia związaną z właściwym przeżywaniem wieku starczego, należy zwrócić uwagę na konieczność nieustannego rozwoju duchowego człowieka9 . Na tym etapie człowiek ma już za sobą piękno swojego ciała oraz bystrość umysłu. Trzeba zatem umieć wejść w sposób sobie właściwy w nowy etap swojego życia, który niekoniecznie musi wiązać się z ograniczonością i poczuciem bezużyteczności ${ }^{10}$. Jak podkreślił Jan Paweł II we wspomnianej adhortacji apostolskiej Christifideles laici:

To, że dziś w wielu krajach wzrasta liczba ludzi starszych i że obniża się granica wieku emerytalnego, otwiera przed ludźmi starszymi nowe możliwości kontynuowania przez nich pracy apostolskiej, którą winni oni odważnie podejmować, pokonując w zdecydowany sposób pokusy nostalgicznego zamykania się we wspomnieniach z przeszłości, która już nie wróci, lub wycofania się z zaangażowania w teraźniejszość z powodu nowych trudności napotykanych w świecie; przeciwnie, winni coraz jaśniej sobie uświadamiać, że ich rola w Kościele i społeczeństwie nie kończy się z wiekiem, leczjedynie przybiera nową formę. Jak mówi Psalmista: „Wydadzą owoc nawet i w starości pełni soków i zawsze żywotni, aby świadczyć, że Pan jest sprawiedliwy" (Ps 92, 15-16) (ChL 48).

W swoim Testamencie nasz święty zaznaczył, że czas jesieni życia to także czas wspomnień, ale nade wszystko czas dziękczynienia. Pisze tam m.in.:

W miarę, jak zbliża się kres mego ziemskiego życia, wracam pamięcią do jego początku, do moich Rodziców, Brata i Siostry (której nie znałem, bo zmarła przed moim narodzeniem), do wadowickiej parafii, gdzie zostałem ochrzczony, do tego miasta mojej młodości, do rówieśników, koleżanek i kolegów ze szkoły podstawowej, z gimnazjum, z uniwersytetu, do czasów okupacji, gdy pracowałem jako robotnik, a potem do parafii w Niegowici i krakowskiej św. Floriana, do duszpasterstwa akademickiego, do środowiska, [...] do wielu środowisk [...] w Krakowie, w Rzymie [...], do osób, które Pan mi szczególnie powierzył - wszystkim pragnę powiedzieć jedno: Bóg Wam zapłać! (Testament).

9 Zob. M. Chmielewski, Rozwój duchowy, [w:] Leksykon duchowości katolickiej, pod red. M. Chmielewskiego, Lublin-Kraków 2002, s. 763-766.

10 Jan Paweł II, Testament, Kraków 2005 [dalej: Testament]; zob. A. Pronzato, Starość czasem nadziei, dz. cyt., s. 31-32. 
Dla Jana Pawła II ważnym elementem dobrze przeżytego życia jest umiejętność odczytywania w świetle wiary różnych trudnych doświadczeń czy sytuacji związanych chociażby z zagrożeniem życia. Dla papieża takim momentem był m.in. zamach na jego życie. Wydarzenie to skomentował w następujący sposób:

W dniu 13 maja 1981 r., w dniu zamachu na papieża podczas audiencji na placu św. Piotra, Opatrzność Boża w sposób cudowny ocaliła mnie od śmierci. Ten, który jest jedynym Panem życia i śmierci, sam mi to życie przedłużył, niejako podarował na nowo. Odtąd ono jeszcze bardziej do Niego należy. Ufam, że On Sam pozwoli mi rozpoznać, dokąd mam pełnić te posługę, do której mnie wezwał w dniu 16 października 1978. Proszę Go, ażeby raczył mnie odwołać wówczas, kiedy sam zechce. W życiu i śmierci do Pana należymy... Pańscy jesteśmy (por. Rz 14, 8). Ufam też, że dokąd dane mi będzie spełniać Piotrową posługę w Kościele, Miłosierdzie Boże zechce użyczać mi sił do tej posługi nieodzownych (Testament).

Jan Paweł II podkreślił w ten sposób, że jesień życia jest okazją do głębokiej refleksji nad tym, co minęło, i czasem uświadomienia sobie szczególnej opieki ze strony Boga ${ }^{11}$.

\section{Starość w Biblii}

Święty Jan Paweł II, wskazując na jesień życia, ukazuje ją także w perspektywie biblijnej. Słowo Boże mówi z wielkim szacunkiem o osobach w podeszłym wieku. Podkreśla, że długowieczność jest postrzegana jako wyraz Bożej łaskawości (por. Rdz 11, 10-32). W tym kontekście długie życie Abrahama staje się przywilejem, którego wyrazem jest obietnica i błogosławieństwo: „Uczynię bowiem z ciebie wielki naród, będę ci błogosławił i twoje imię rozsławię: staniesz się błogosławieństwem. Będę błogosławił tym, którzy ciebie błogosławić będą, a tym, którzy tobie będą złorzeczyli, i ja będę złorzeczył. Przez ciebie będą otrzymywały błogosławieństwo ludy całej ziemi" (Rdz 12, 2-3). Podobnie i Mojżesz jest już w podeszłym wieku, gdy Bóg powierza mu misję wyprowadzenia narodu wybranego z niewoli egipskiej. Z polecenia Bożego dokonuje wielkich dzieł, stając się narzę-

11 Zob. S. Kowalczyk, Podstawy światopoglądu chrześcijańskiego, Wrocław 1995, s. 421-435. 
dziem w Jego ręku. Spośród innych postaci, jak zauważa Jan Paweł II, należy wymienić Tobiasza, który z pokorą i odwagą serca stara się przestrzegać prawa Bożego, wspomaga potrzebujących oraz znosi doświadczenie ślepoty do momentu doznania uzdrowienia za sprawą anioła posłanego przez Boga (zob. Tb 1-2). Także i męczeństwo Eleazara staje się świadectwem szczególnej ofiarności oraz postawy męstwa (por. 2 Mch 6, 18-31) ${ }^{12}$. Wszystkie te osoby ukazują swoim życiem, że zaufanie Bogu obfituje doświadczeniem Jego błogosławieństwa ${ }^{13}$.

W Nowym Testamencie na szczególną uwagę zasługują Elżbieta i Zachariasz - rodzice Jana Chrzciciela. Dostąpili oni Bożego miłosierdzia jako posunięci już w latach. Zachariasz otrzymał zapowiedź narodzin syna, choć jak sam podkreślił: ,,jestem już stary i moja żona jest w podeszłym wieku" (Łk 1, 18). Kolejne postacie to starzec Symeon i prorokini Anna. Symeon jawi się jako ten, który wyczekuje od dawna Zbawiciela i jest świadkiem ofiarowania Pańskiego. Wyrazem jego radości są wypowiedziane przez niego następujące słowa: „Teraz, o Władco, pozwól odejść słudze Twemu w pokoju [...], bo moje oczy ujrzały Twoje zbawienie" (Łk 2, 29-30). Prorokini Anna sławiła zaś Boga i rozpowiadała o Nim wszystkim, którzy oczekiwali wyzwolenia Jerozolimy (zob. Łk 2, 38). W ten sposób św. Jan Paweł II przypomniał całemu światu, że doświadczenie spotkania z Panem zawsze winno owocować świadectwem życia.

Pośród osób będących w jesieni życia nie można pominąć Nikodema, członka Sanhedrynu, któremu Jezus objawia się jako Syn Boży; Piotra, który pozwala prowadzić się Jezusowi tam, dokąd On chce $(\mathrm{J} 21,18)$.

Podsumowując zatem etap starości rozważany w kontekście powołania ukazanego w Biblii, należy podkreślić za Janem Pawłem II, że człowiek stary ukazany jest jako uosobienie kogoś, kto jest pełen mądrości i bojaźni Bożej (zob. ChL 48). Starość jawi się więc jako czas pomyślny, w którym następuje dopełnienie miary ludzkiego życia. Starość jest, jak czytamy w Księdze Mądrości, czcigodna nie tyle poprzez liczbę przeżytych lat, ile przede wszystkim poprzez mądrość i życie nieskalane. Jest to ostatni etap ludzkiego dojrzewania, a zarazem znak Bożego błogosławieństwa (List 8).

12 Zob. Jan Paweł II, List Do moich Braci i Sióstr - ludzi w podeszłym wieku [dalej: List], 6-8.

13 Zob. C. Parzyszek, Nowa ewangelizacja - droga Kościoła do nadziei, Ząbki 2010, s. 102-151. 
W ten sposób przypomina, że w służbie Ewangelii wiek nie ma istotnego znaczenia.

\section{Mądrość owocem jesieni życia}

Spoglądając na jesień życia, można by ją określić jako obecność w Kościele i społeczeństwie świadków tradycji wiary, nauczycieli życia oraz krzewicieli miłości (ChL 48). W liście Do moich Braci i Sióstr - ludzi w podeszłym wieku Jan Paweł II ukazuje ich szczególną rolę w życiu Kościoła i społeczeństwa. Papież tak pisze:

Ludzie starzy przypominają nam, jak mądrzej patrzeć na ziemskie wydarzenia, ponieważ dzięki życiowym doświadczeniom zyskali wiedzę i dojrzałość. Są strażnikami pamięci zbiorowej, a więc mają szczególny tytuł, aby być wyrazicielami wspólnych ideałów i wartości, które są podstawą i regułą życia społecznego. Wykluczyć ich ze społeczeństwa znaczy w imię nowoczesności pozbawionej pamięci odrzucić przeszłość, w której zakorzeniona jest teraźniejszość. Ludzie starsi dzięki swej dojrzałości i doświadczeniu mogą udzielać młodym rad i cennych pouczeń (List 10 ).

Według Jana Pawła II czas jesieni życia to również okazja do przypomnienia wzajemnej zależności pokoleniowej, ponieważ natura ludzka rozwija się dzięki obecności drugiego człowieka. Ważne zatem jest wzajemne ubogacanie się bagażem doświadczeń życiowych będących owocem mądrości serca. Każdy bowiem człowiek potrzebuje drugiej osoby i wzbogaca się dzięki jej darom i charyzmatom. Dlatego chrześcijańska wspólnota może wiele skorzystać dzięki obecności osób w jesieni życia. Jan Paweł II wskazuje tu m.in. na sferę ewangelizacji i podkreśla:

[...] jej skuteczność nie zależy w głównej mierze od sprawnego działania. W jakże wielu rodzinach wnuki poznają podstawy wiary dzięki dziadkom! Jednak ludzie starsi mogą wnosić dobroczynny wkład także w wielu innych dziedzinach. Duch działa, jak i gdzie chce, nierzadko posługując się ludzkimi środkami, które uchodzą w oczach świata za mało znaczące. Wiele osób znajduje zrozumienie i wsparcie u ludzi starych, samotnych i chorych, ale umiejących dodać otuchy poprzez życzliwą radę, milczącą modlitwę, świadectwo cierpienia znoszonego z wytrwałą ufnością. Właśnie wówczas, gdy słabną ich siły i zdolność działania, nasi sędziwi bracia i siostry stają się szczególnie cennymi narzędziami tajemnych zamysłów Opatrzności (List 13). 
Tak więc osoby starsze stają się darem dla każdego społeczeństwa. Wobec sytuacji, w których próbuje się marginalizować rolę osób starszych, należy zatem stwierdzić, że jesień życia staje się bogactwem społeczeństw.

Pytając o miejsce, w którym najlepiej przeżywa się starość życia, ojciec święty wskazuje, że „najbardziej naturalnym środowiskiem przeżywania starości jest przede wszystkim to, w którym człowiek w podeszłym wieku czuje się u siebie, tzn. wśród krewnych, znajomych, przyjaciół oraz tam, gdzie może czuć się jeszcze potrzebnym" (List 13). W miarę wzrastania długości ludzkiego życia i zwiększającej się liczby ludzi starszych należy krzewić kulturę, która będzie akceptować i cenić jesień ludzkiego życia, a nie spychać ją na margines społeczeństwa. Dlatego też niezbędne staje się zwrócenie uwagi na skuteczną pomoc socjalną adekwatną do potrzeb starszych osób, związanych często z pogarszającym się stanem zdrowia (zob. List 13).

Poprzez otaczanie szacunkiem i miłością osób starszych społeczeństwo staje się kontynuatorem dziedzictwa, które przekazywane jest z pokolenia na pokolenie. Spoglądając zaś na osoby w jesieni życia, zwłaszcza na ich pogodę ducha i mądrość życiową, możemy sami właściwie wykorzystać obecny czas, wiedząc, że „dziś” będzie owocowało „jutro" ${ }^{14}$.

\section{Przygotowanie do wieczności}

W liście do swoich braci - ludzi będących w jesieni życia papież zaznaczył:

jest czymś naturalnym, że z upływem lat oswajamy się z myślą o zmierzchu życia. Przypomina nam o tym choćby fakt, że szeregi naszych krewnych, przyjaciół i znajomych coraz bardziej się przerzedzają: uświadamiamy sobie przy różnych okazjach, na przykład gdy spotykamy się z najbliższymi, w gronie kolegów z dzieciństwa, szkoły, ze studiów, z wojska czy z seminarium... Granica życia i śmierci przesuwa się przez nasze wspólnoty i stale przybliża się do każdego z nas. Jeśli życie jest pielgrzymką do niebieskiej ojczyzny, to starość jest czasem, gdy jesteśmy najbardziej skłonni myśleć o wieczności (List 14).

14 Zob. J. Kiciński, Etapy formacji na tle współczesnych zagrożen, [w:] Formacja dzisiaj do życia konsekrowanego jutra, red. J. Tupikowski, Warszawa-Wrocław 2002, s. 124-137. 
W swoim Testamencie pod datą 6 marca 1979 roku Jan Paweł II przywołuje słowa z Ewangelii św. Mateusza:

Czuwajcie, bo nie wiecie, kiedy Pan wasz przybędzie (por. Mt 24, 42) - te słowa przypominają mi ostatecznie wezwanie, które nastąpi wówczas, kiedy Pan zechce. Pragnę za Nim podążyć i pragnę, aby wszystko, co składa się na moje ziemskie życie, przygotowało mnie do tej chwili. Nie wiem, kiedy ona nastąpi, ale tak jak wszystko, również i tę chwilę oddaję w ręce Matki mojego Mistrza: Totus Tuus. W tych samych Rękach Matczynych zostawiam wszystko i Wszystkich, z którymi związało mnie moje życie i moje powołanie. W tych Rękach zostawiam nade wszystko Kościół, a także mój naród i całą ludzkość. Wszystkim dziękuję. Wszystkich proszę o przebaczenie. Proszę także o modlitwę, aby miłosierdzie Boże okazało się większe od mojej słabości i niegodności (Testament).

Podczas rekolekcji, które odprawiał między 24 lutego a 1 marca 1980 roku, zanotował następujące słowa:

z możliwością śmierci każdy zawsze musi się liczyć. I zawsze musi być przygotowany do tego, że stanie przed Panem i Sędzią - a zarazem Odkupicielem i Ojcem. [...] Pragnę raz jeszcze całkowicie zdać się na Wolę Pana. On sam zdecyduje, kiedy i jak mam zakończyć moje ziemskie życie i pasterzowanie. W życiu i śmierci Totus Tuus przez Niepokalaną. Przyjmując już teraz tę śmierć, ufam, że Chrystus da mi łaskę owego ostatniego Przejścia, czyli Paschy. Ufam też, że uczyni ją pożyteczną dla tej największej sprawy, której staram się służyć: dla zbawienia ludzi, dla ocalenia rodziny ludzkiej, a w niej wszystkich narodów i ludów (wśród nich serce w szczególny sposób zwraca się do mojej ziemskiej Ojczyzny), dla osób, które szczególnie mi powierzył - dla sprawy Kościoła, dla chwały Boga Samego (Testament, 24.02-1.03.1980).

Słowa te w sposób szczególny wskazują na dojrzałość duchową Jana Pawła II, który pragnął podzielić się z innymi swoim doświadczeniem wiary. Jest to wyraz bezgranicznego zaufania Bogu, wiary w Jego Opatrzność, która czuwa nad nami każdego dnia.

Ponadto papież podkreśla, że wiara

rozjaśnia tajemnicę śmierci i opromienia swym światłem starość, która nie jest już przegrana i przeżywana jako moment biernego oczekiwania na śmierć. Lata te należy przeżywać w postawie ufnego zwierzenia Bogu. Ten czas należy twórczo spożytkować, dążąc do pogłębienia życia duchowego poprzez usilną modlitwę i gorliwą służbę braciom w miłości (List 16).

Tak więc jesień ludzkiego życia może stać się okazją do wypłynięcia na głębię ducha i otwarcia się na nieskończoność miłosierdzia Bożego. 


\section{Zakończenie}

Na końcu warto przytoczyć słowa Jana Pawła II ze wspomnianego listu Do moich Braci i Sióstr - ludzi w podeszłym wieku, w którym papież zwraca się słowami pełnymi miłości do osób chorych i cierpiących:

Drodzy ludzie starzy, trapieni przez kłopoty ze zdrowiem lub problemy innego rodzaju, jestem całym sercem z wami. Kiedy Bóg przyzwala, abyśmy cierpieli z powodu choroby, samotności lub z innych przyczyn związanych z podeszłym wiekiem, zawsze obdarza nas łaską i mocą, byśmy z jeszcze większą miłością włączali się w ofiarę Jego Syna i głębiej uczestniczyli w realizacji Jego zbawczego zamysłu. Możemy być pewni, że On jest ojcem bogatym w miłość i miłosierdzie!

Pamiętam zwłaszcza o was, wdowcy i wdowy, którzy zostaliście sami na ostatnie lata swego życia; o was, osoby konsekrowane oraz drodzy bracia w kapłaństwie [...]. Kościół nadal was potrzebuje. Wysoko ceni sobie wasze przysługi, jakie nadal jesteście gotowi spełniać w różnych dziedzinach apostolatu, liczy na wasz wkład wytrwałej modlitwy, oczekuje od was wyważonych rad i wzbogaca się dzięki ewangelicznemu świadectwu, jakie składacie każdego dnia (List 13).

Słowa te zostały w pełni potwierdzone osobistym świadectwem życia, jakie Jan Paweł II złożył wobec całego świata, przechodząc do domu Ojca 2 kwietnia 2005 roku o 21.37. 


\section{Summary}

The autumn of life - the call for the chosen

The author of the article shows the teaching of saint John Paul II on the presence and role of elderly people in the Church and society. Thus the author describes the care of the Pope for people in the autumn of their life. The last stage of life is shown here as a direct preparation for meeting God in eternity. In the article the following issues are taken into account: the person's vocation as a gift and task, good life, old age in the Bible, wisdom as a fruit of maturity and preparation for eternity.

Keywords: John Paul II, old age, vocation, eternity

\section{Jesień życia - powołanie dla wybranych}

Autor artykułu ukazuje spojrzenie św. Jana Pawła II na obecność osób w podeszłym wieku w Kościele i społeczeństwie. Ukazuje zatroskanie papieża o człowieka przeżywającego jesień swojego życia. Ważne staje się pozytywne spojrzenie na ostatni etap ludzkiego życia, który jest bezpośrednim przygotowaniem do spotkania z Bogiem w wieczności. Omówione zostają tu takie zagadnienia,jak: powołanie człowieka darem i zadaniem; dobrze przeżyć dar życia; starość w Biblii; mądrość owocem jesieni życia oraz przygotowanie do wieczności.

Słowa kluczowe: Jan Paweł II, starość powołanie, wieczność

\section{Bibliografia}

Katechizm Kościoła katolickiego, Poznań 1994, 2012-2016.

Jan Paweł II, Encyklika Redemptor hominis.

Jan Paweł II, Adhortacja apostolska Christifideles laici .

Jan Paweł II, Przemówienie do przedstawicieli ludzi starszych z włoskich diecezji (23 marca 1984), „Insegnamenti” VII (1984), 1.

Jan Paweł II, List Do moich Braci i Sióstr - ludzi w podeszłym wieku (1.10.1999).

Jan Paweł II, Testament, Kraków 2005.

Chmielewski M., Rozwój duchowy, [w:] Leksykon duchowości katolickiej, red. M. Chmielewski, Lublin-Kraków 2002, s. 763-766.

Kiciński J., Duchowość wieku starczego, „Poznańskie Zeszyty Humanistyczne” VI (2006), s. 7-12.

Kiciński J., Jesień życia - koniec czy poczatek, „Studia Salvatoriana Polonica” 6 (2012), s. 213.

Kiciński J., Etapy formacji na tle wspótczesnych zagrożeń, [w:] Formacja dzisiaj do życia konsekrowanego jutra, red. J. Tupikowski, Warszawa-Wrocław 2002, s. 124-137. 
Kowalczyk S., Podstawy światopoglądu chrześcijańskiego, Wrocław 1995.

Parzyszek C., Nowa ewangelizacja - droga Kościoła do nadziei, Ząbki 2010.

Pronzato A., Starość czasem nadziei, przeł. A. Ryndak-Laciuga, Kraków 2005.

Zyzak W., Co mam czynić, aby osiagnać życie wieczne? Duchowość chrześcijańska na świeckiej drodze życia, Kraków 2008. 